\title{
Reduced Variability of Endurance Time in New Protocols for Exercise Tests in COPD [Corrigendum]
}

Tufvesson E, Radner F, Papapostolou G, et al. Int J Chron Obstruct Pulmon Dis. 2020;15:3003-3012.

Page 3004, left column, line 2 from the bottom, the sentence "The study also included a new $\mathrm{W}_{\text {MAX }}$ test where the participants started biking with a 3-min warm-up at $40 \%$ of their predicted $\mathrm{W}_{\mathrm{MAX}}$, followed by an instant increase to $70 \%$ and then a linear increase in workload to achieve the predicted $\mathrm{W}_{\text {MAX }}$ within 8 min" should read "The study also included a new $\mathrm{W}_{\mathrm{MAX}}$ test where the participants started biking with a 3-min warm-up at $40 \%$ of their predicted $\mathrm{W}_{\mathrm{MAX}}$, followed by a linear increase in workload to achieve the predicted $\mathrm{W}_{\text {MAX }}$ within 8 min".
Page 3005, left column, line 4 from the bottom, the sentence "The new maximum test included an initial phase of pedalling for 3 min at $40 \%$ (Study A) or 30\% (Study B) of the predicted $\mathrm{W}_{\mathrm{MAX}}$, followed by an instant increase to $75 \%$ (Study A) or 70\% (Study B), followed by a stepwise (Study A) or linear (Study B) increase in workload until exhaustion" should read "The new maximum test included an initial phase of pedalling for $3 \mathrm{~min}$ at $40 \%$ (Study A) or $30 \%$ (Study B) of the predicted $\mathrm{W}_{\mathrm{MAX}}$, followed by a linear increase in workload to achieve the predicted $\mathrm{W}_{\text {MAX }}$ within 8 min".

The authors apologize for these errors.

\section{Publish your work in this journal}

The International Journal of COPD is an international, peer-reviewed journal of therapeutics and pharmacology focusing on concise rapid reporting of clinical studies and reviews in COPD. Special focus is given to the pathophysiological processes underlying the disease, intervention programs, patient focused education, and self management protocols. This journal is indexed on PubMed Central, MedLine and CAS. The manuscript management system is completely online and includes a very quick and fair peer-review system, which is all easy to use. Visit http://www.dovepress.com/testimonials.php to read real quotes from published authors. 